\begin{tabular}{|c|c|}
\hline $\begin{array}{l}\text { ний університет імені Івана Огієнка (Кам'янець- } \\
\text { Подільський, Україна) }\end{array}$ & Ohiienko University (Kamianets-Podilskyi, Ukraina) \\
\hline \multicolumn{2}{|l|}{$\begin{array}{l}\text { e-mail: bodnar.alina@kpnu.edu.ua } \\
\text { https://orcid.org/0000-0002-8921-3656 }\end{array}$} \\
\hline $\begin{array}{l}\text { Юрчишин Юрій Володимирович - кандидат наук } \\
3 \text { фізичного виховання та спорту, доцент, Кам’я- } \\
\text { нець-Подільський національний університет імені } \\
\text { Івана Огієнка (Кам'янець-Подільський, Україна) }\end{array}$ & $\begin{array}{l}\text { Yurchyshyn Yurii Volodymyrovych - Candidate of } \\
\text { Science (Education), Associate Professor (Ph. D.), } \\
\text { Kamianets-Podilskyi National Ivan Ohiienko Uni- } \\
\text { versity (Kamianets-Podilskyi, Ukraina) }\end{array}$ \\
\hline \multicolumn{2}{|l|}{$\begin{array}{l}\text { e-mail: yuriyyurchyshyn @ kpnu.edu. } \\
\text { https://orcid.org/0000-0002-0404-9384 }\end{array}$} \\
\hline $\begin{array}{l}\text { Стасюк Іван Іванович - кандидат наук з фізично- } \\
\text { го виховання та спорту, доцент, Кам'янець-Поділь- } \\
\text { ський національний університет імені Івана Огієн- } \\
\text { ка (Кам'янець-Подільський, Україна) }\end{array}$ & $\begin{array}{l}\text { Stasiuk Ivan Ivanovych - Candidate of Science } \\
\text { (Education), Associate Professor (Ph. D.), Kamianets- } \\
\text { Podilskyi National Ivan Ohiienko University } \\
\text { (Kamianets-Podilskyi, Ukraina) }\end{array}$ \\
\hline $\begin{array}{l}\text { e-mail: stasuik.ivan@ kpnu.edu.ua } \\
\text { https://orcid.org/0000-0002-4504-5902 }\end{array}$ & \\
\hline
\end{tabular}

УДК 378.014.6.093.5:796

doi: 10.15330/fcult.33.26-34
Ірина Бондаренко, Оксана Дзюбан, Геннадій Кураса, Олег Бондаренко

\title{
ПРО ЯКІСТЬ ОСВІТНЬОГО ПРОЦЕСУ НА ФАКУЛЬТЕТІ ФІЗИЧНОГО ВИХОВАННЯ І СПОРТУ \\ (на прикладі Чорноморського національного університету імені Петра Могили)
}

\footnotetext{
Метою дослідження слугувало підвищення якості освітнього процесу на факультеті фізичного виховання та спорту в ЧНУ імені Петра Могили.

В анкетуванні (2019 р.) взяло участь 158 студентів. Визначено рейтинг провідних мотивів щзодо вибору майбутньої професійної діяльності: власне бажання (33,2\%), престиж професії (15,5\%), можливість подальшого працевлаштування $(13,7 \%)$.

Якість вищої освіти в університеті більшість студентів охарактеризували як “високу” та “дуже високу” (77,2\%). Майже чверть респондентів відмітило (25,3\%), щуо не задоволені критеріями оцінювання. Більшість студентів задоволені рівнем організації та проведення лекцій з профільних (93,1\%) та непрофільних предметів (89,8\%). Більшість опитаних студентів не розчарувалися у виборі щзодо факультету та спеціальності (72,2\%).

Опитування сприяє прочесу двосторонньої взаємодї між викладачами й студентами. Розробляються заходи щзодо вдосконалення робочих програм з непрофільних дисциплін.

Ключові слова: анкетування, студент, спеціальність, мотив, якість освіти.
}

The purpose of the research: to improve the quality of the educational process in higher education at the Faculty of Physical Education and Sports by tracking the attitude of students to the educational process at the Petro Mohyla National University.

Methods of research: The survey was carried out during January-February 2019. The survey was attended by 158 students studying at the Faculty of Physical Education and Sports. The method of analysis of scientific sources and methods of mathematical statistics is applied.

Research results._Students determined the rating of leading motives in choosing future professional activities: their own desire (33.2\%), prestige of the profession (15.5\%), the possibility of further employment (13.7\%).

The quality of higher education at the university was characterized by the majority of students as "high" and "very high" (77.2\%).

More than half of the interviewed students (57.0\%) believe that the criteria for evaluating their knowledge and skills are always transparent and understandable. Almost a quarter of respondents noted (25.3\%) that they are not satisfied with the criteria of evaluation. 
Most students are satisfied with the level of organization and conducting lectures on profile (93.1\%) and non-core subjects (89.8\%). The lowest level of students' satisfaction with the level of organization and conducting of lectures and practical, seminars on non-core disciplines.

The rating of qualities of teachers, which according to students is the most important, is determined:

1) the competence in the subject,

2) interest in ensuring that students get high-quality knowledge

3) nonconventional conduct of classes, creativity

4) democratic attitude towards students

5) objectivity in the assessment of students' achievements.

Most of the students surveyed were not disappointed with the choice of faculty and specialty (72.2\%).

Conclusions The survey contributes to the process of bilateral interaction between teachers and students. Measures are being developed to improve work programs in disciplines. It is necessary to draw the attention of teachers of non-core disciplines to the quality of teaching subjects, to update both lecture courses and practical classes, taking into account the specifics of the specialty in which teaching is conducted.

Key words: questionnaire, student, specialty, motive, quality of education.

Постанова проблеми. У 2015 р. А.С. Мендес, директор у справах молоді та спорту Головного Управління освіти і культури Європейської комісії, зазначив, що Європа відновить зростання тільки в тому випадку, якщо буде формувати висококваліфіковані кадри, які зможуть внести свій вклад в інновації та підприємництво. На його думку, необхідно встановити новий підхід до освіти для спортивних професій, який призведе до найкращої відповідності між потребами суспільства, вимогами ринку праці та запропонованою кваліфікацією [5].

Як зазначено на офіційному сайті Міністерства освіти і науки України, якість освіти - комплекс характеристик освітнього процесу, що визначають послідовне та практично ефективне формування компетентності та професійної свідомості. Це певний рівень знань і вмінь, розумового, фізичного й морального розвитку, якого досягли випускники освітнього закладу відповідно до запланованих цілей навчання і виховання [6]. Одним з головних компонентів, що сприяють визначенню рівня якості вищої освіти $\epsilon$ стандарти вищої освіти. Стандарт вищої освіти за спеціальністю 227 “Фізична терапія, ерготерапія” галузі знань 22 “Охорона здоров'я” (ступінь вищої освіти - бакалавр) було затверджено та введено в дію з 2018-2019 н.р. (Наказ МОН України, №1419) [7]. Міністерством освіти та науки України розглядаються проекти стандартів вищої освіти (ступінь вищої освіти - магістр) за спеціальністю 227 “Фізична терапія, ерготерапія" та 017 “Фізична культура і спорт”. Таким чином, стандарти вищої освіти знаходяться у стадії обговорення проектів.

Система забезпечення якості освітньої діяльності та якості вищої освіти в України висвітлена в Законі України “Про вищу освіту” (від 01.07.2014 р. №1556-VII, чинний). Перша частина статті № 16 вищезазначеного нормативного документу розкриває структуру системи забезпечення якості вищої освіти:

1) система внутрішнього забезпечення якості;

2) система зовнішнього забезпечення якості освітньої діяльності;

3) система забезпечення якості діяльності Національного агентства та незалежних установ із забезпечення якості вищої освіти.

Таким чином, у навчальному закладі передбачено проведення процедур: здійснення моніторингу та періодичного перегляду освітніх програм; щорічне оцінювання здобувачів вищої освіти, науково-педагогічних і педагогічних працівників; забезпечення підвищення кваліфікації педагогічних працівників; забезпечення наявності необхідних ресурсів для організації освітнього процесу та наявності інформаційних систем для ефективного управління цим процесом [2]. Тому, моніторинг думок студентів як споживачів освітніх послуг, вивчення їх потреб, запитів, інтересів, настроїв, а також мотивів навчальної діяльності дозволяє вчасно виявляти та відстежувати проблеми в 
освітньому процесі, оперативно на них реагувати, корегуючи організацію навчальної, виховної та профорієнтаційної роботи в університеті.

Актуальність дослідження визначена невідповідністю між підвищеними вимогами до якості вищої освіти в галузі фізичної культури та недостатнім рівнем повільним впровадженням педагогічних інновацій, оновленням програм підготовки, станом матеріальних ресурсів університетів та ін.

Аналіз останніх досліджень і публікацій. Відомий педагог А. Шлейхер відмічає, що диплом не є гарантією успіху, в цифрову епоху технології знову випереджають навички людей, а зростання безробіття серед випускників у більшості промислово розвинених країн світу викликає тривогу. Автор наголошує: “Діти, що ростуть із чудовими смартфонами, але поганою освітою, матимуть справу з безпрецедентними викликами, найменше, ... що ми можемо зробити зараз, - скористатися своїми можливостями перетворення освіти". Успіх в освіті полягає вже не у відтворенні знань, а в екстраполяції того, що знає людина, та як творчо застосовує ці знання у нових ситуаціях. Наголошено, що це також стосується й мислення, що не обмежується межами окремих дисциплін [8].

Р. Карпюк (2015) в науковій публікації надав характеристики стратегії підвищення якості вищої фізкультурної освіти. Елементами системи підтримки високого рівня якості вищої фізкультурної освіти повинні слугувати нові Державні стандарти, система сертифікації постійного підвищення кваліфікації фахівців фізкультурного профілю, система соціокультурних чинників модернізації вищої фізкультурної освіти, система соціальних й економічних стимулів для професійного зростання та підвищення статусу вчителя фізичної культури (тренера, фахівця з реабілітації) в суспільстві та ін. [3].

B.С. Мозальов, аналізуючи вітчизняний та зарубіжний досвід моніторингу якості освіти, відмічає, що в багатьох університетах України використовують систематичне збирання дослідницькими методами відомостей про навчально-виховний процес 3 метою визначення оптимальних шляхів підвищення якості освіти і прийняття відповідних управлінських рішень (НПУ імені М.П. Драгоманова); оцінюють роботи науково-педагогічних працівників університету, визначають рейтингів викладачів, кафедр та факультетів університету (ВНАУ); здійснюють аналіз даних щодо анкетування студентів 3 актуальних питань, визначених Вченою радою університету (Київський університет імені Бориса Грінченка) [4].

В ЧНУ ім. Петра Могили нами було проведено ряд соціологічних досліджень, в одному з них нами аналізувалися проблеми підготовки майбутнього вчителя з фізичного виховання (2017). Зазначено, що студенти 4 курсу факультету фізичного виховання і спорту (більш 40\%) володіють високим та вище середнього рівнем мотивації до подальшого вдосконалення вмінь, формування знань щодо майбутньої професії. Деякі пропозиції четвертокурсників можна врахувати щодо підвищення рівня навчального процесу, зокрема посилити процеси комп'ютеризації [1].

Мета дослідження - підвищення якості освітнього процесу у вищій освіті на факультеті фізичного виховання та спорту за допомогою фіксації та відстеження ставлення студентів до навчального процесу в університеті, аналізі динаміки їх оцінок стосовно напрямів роботи ЧНУ імені Петра Могили.

Завдання дослідження: узагальнення наукових джерел, нормативних документів, щодо проблеми підвищення якості освіти фізкультурного профілю; узагальнення оцінних суджень студентів щодо якості освітнього процесу з метою вдосконалення навчального процесу; обгрунтування заходів щодо поліпшення якості вищої фізкультурної освіти.

Методи дослідження: Опитування здійснювалось протягом січня-лютого 2019 р. в Чорноморському національному університеті імені Петра Могили з використання методу анкетування. До проведення анкетування були залучені представники студентсь- 
кого самоврядування та провідні фахівці кафедр. Звіт складено кандидатами соціологічних наук Л. Калашніковою та В. Чорною. В анкетуванні взяло участь 2234 студенти (з них $39,9 \%$ юнаків та $60,1 \%$ дівчат). Із загального числа опитаних студентів $52,7 \%$ навчаються на контрактній основі й 47,3\% - на бюджетній.

Нами було проаналізована вибіркова сукупність серед студентів, які навчаються на факультеті фізичного виховання та спорту, що склала 158 осіб.

Застосовано метод аналізу наукових джерел та методи математичної статистики.

Результати дослідження. Одним з провідних чинників, що визначає успіх підготовки спеціалістів вищої кваліфікації, є мотивація навчання. Всі мотиви умовно можна поділити на внутрішні (власні бажання, інтереси) та зовнішні (престиж професії чи закладу вищої освіти, можливість подальшого працевлаштування, високій рівень майбутньої зарплати, поради знайомих). Від того наскільки адекватно вмотивованим буде вибір майбутньої професії залежить узгодження життєвих планів молоді та наміри професійної реалізації, тому характер мотивації вибору визначає й подальшу навчальну поведінку.

Визначено рейтинг провідних мотивів щодо вибору майбутньої професійної діяльності студентами факультету фізичного виховання та спорту в ЧНУ ім. Петра Могили:

- власне бажання $(33,2 \%)$,

- престиж професії (15,5\%),

- можливість подальшого працевлаштування (13,7\%),

- поради батьків, родичів, друзів, знайомих $(11,3 \%)$,

• високий рівень майбутньої заробітної плати $(9,8 \%)$

- прийнятна сума оплати за навчання $(5,8 \%)$,

- потрапляння на бюджетне місце (4\%),

- попереднє навчання на курсах ЧНУ ім. П. Могили $(2,4 \%)$,

- бажання навчатися в ЧНУ ім. П. Могили $(2,4 \%)$

Інші варіанти мотивів запропоновано $1,8 \%$ студентів.

Таким чином, вибір майбутньої професії для майже третини студентів є свідомим, що засвідчує переважання індивідуально значимих, внутрішніх мотивів, натомість для інших характерні зовнішні мотиви. Серед інших мотивів вибору спеціальності, означених студентами, були такі, як: близькість розташування університету від дому; відсутність альтернативи вибору з-поміж інших закладів вищої освіти міста; місце, що посідає ЧНУ ім. Петра Могили у рейтингу вищих навчальних закладів регіону.

Забезпечення необхідної й достатньої інформації про діяльність навчального закладу є особливо важливим завданням в умовах посилення конкуренції на ринку освітніх послуг. За оцінними судженнями студентів факультету фізичного виховання та спорту пріоритетними джерелами інформації про діяльність ЧНУ ім. Петра Могили для них $\epsilon$ офіційний сайт університету $(29,0 \%)$ та розповіді родичів, знайомих, друзів (22,0\%). 3-поміж інших джерел інформування студенти означили можливість отримання інформації під час відвідування освітніх порталів (Osvita.ua, Vstup.info тощо) $(10,3 \%)$. Безпосереднє спілкування з фахівцями приймальної комісії ЧНУ ім. П. Могили слугувало джерелом інформації для 9,7\% студентів. Сторінки університету у соціальних мережах допомогли в отриманні інформації 8,3\% майбутнім фахівцям в галузі фізичної культури.

Студенти надали рекомендації удосконалення веб-сторінок університету щодо оновлення наявних рубрик або доповнення новими за напрямами: розклад занять, анонси подій, що відбуваються в університеті, інформація про викладачів (фото, сфера наукових інтересів, актуальна пошта та ін.), рейтинги студентів, інформація про наукові конференції, конкурси, олімпіади, гранти, інформація про навчальні предмети за вибо- 
ром, інформація про факультети, спеціальності та можливості працевлаштування після закінчення університету, програми міжнародного обміну студентами.

Як відомо, студенти є носієм корпоративної культури закладу вищої освіти, його традицій, цінностей, не лише у період навчання, але й після його завершення. I залежно від того, наскільки ці традицій, цінності розділяють представники студентського загалу, вони поширюють позитивну чи негативну інформацію про свій університет. Основним критерієм ефективності діяльності закладу вищої освіти $є$ рівень освіченості студентів. На питання "Як би Ви загалом оцінили якість вищої освіти в ЧНУ ім. Петра Могили?” більшість студентів факультету фізичного виховання охарактеризували як “високу” та “дуже високу” (77,2\%) (рис. 1).

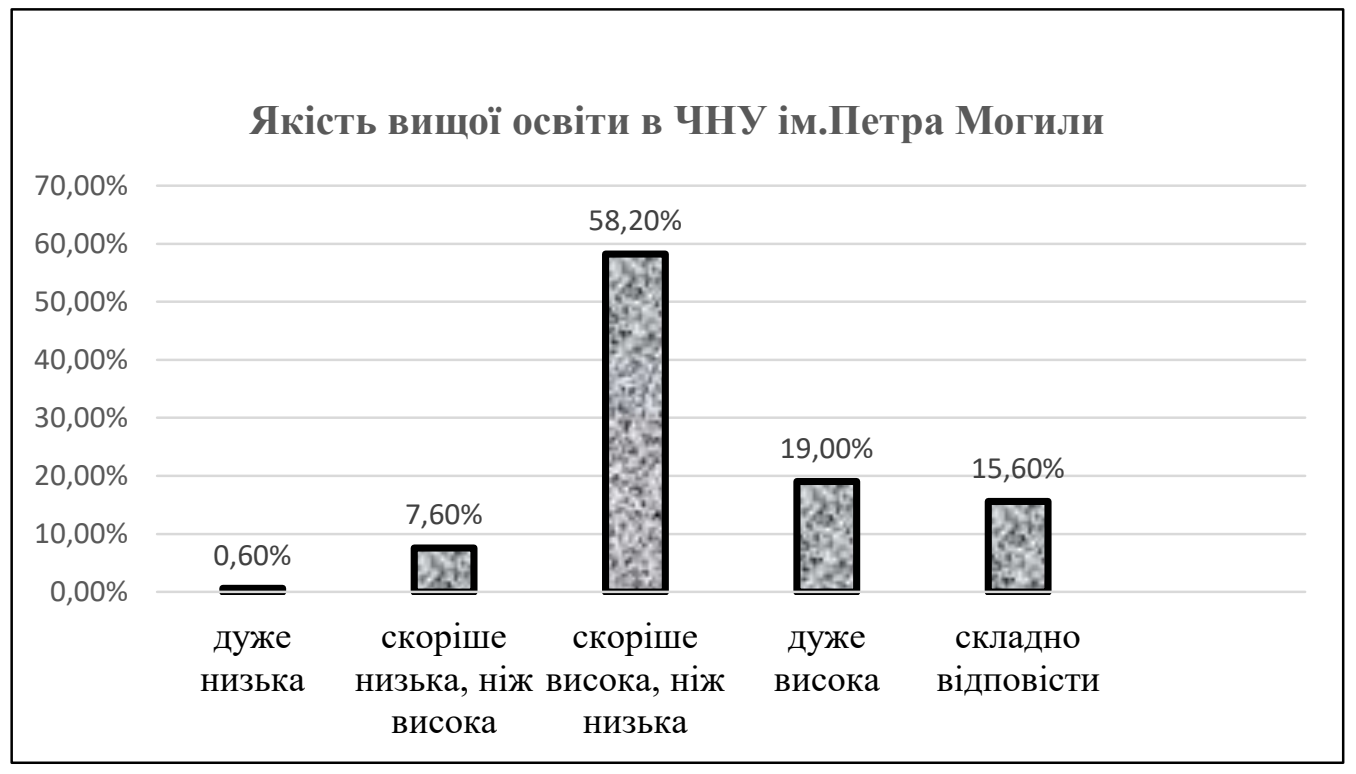

Puc. 1. Оцінні судження студентів щодо якості рівня вищої освіти в Чорноморському національному університеті імені Петра Могили (\%, від загальної кількості опитаних)

Відмічено, що розподіл відповідей за курсами навчання свідчить про те, що 3 плином часу оцінки студентів стають більш критичними - студенти старших курсів оцінюють якість освіти суттєво нижче, ніж молодших курсів.

Як відомо, невід'ємною частиною комплексної оцінки якості освіти є оцінка професіоналізму викладачів, рівня викладання навчальних дисциплін, об'єктивності критеріїв оцінювання знань й вмінь студентів. Більша половина опитаних студентів $(57,0 \%)$ вважають, що критерії оцінювання їх знань й вмінь завжди прозорі й зрозумілі, майже чверть респондентів відмітило (25,3\%), що не задоволені критеріями оцінювання, а 3,8\% студентів охарактеризували критерії як такі, що не відповідають реальним вимогам до якості знань, сформованості вмінь; 13,9\% не змогли визначитися з відповіддю.

На питання “Чи об’єктивно оцінюють викладачі рівень Ваших знань та вмінь під час проведення різних форм контролю (іспити, заліки, контрольні роботи тощо)?” $58,9 \%$ опитаних відмітили постійну об'єктивність; 34,2\% зазначили, що інколи викладачі не об'єктивні, а 1,9\% відмітили відсутність об'єктивного підходу до оцінки рівня знань; 5,1\% респондентів не визначилися з відповіддю.

Більша частина опитаних студентів задоволена повною мірою або частково (разом рівнем організації та проведення лекцій з профільних $(93,1 \%)$ та непрофільних предметів (89,8\%) (рис. 2). 


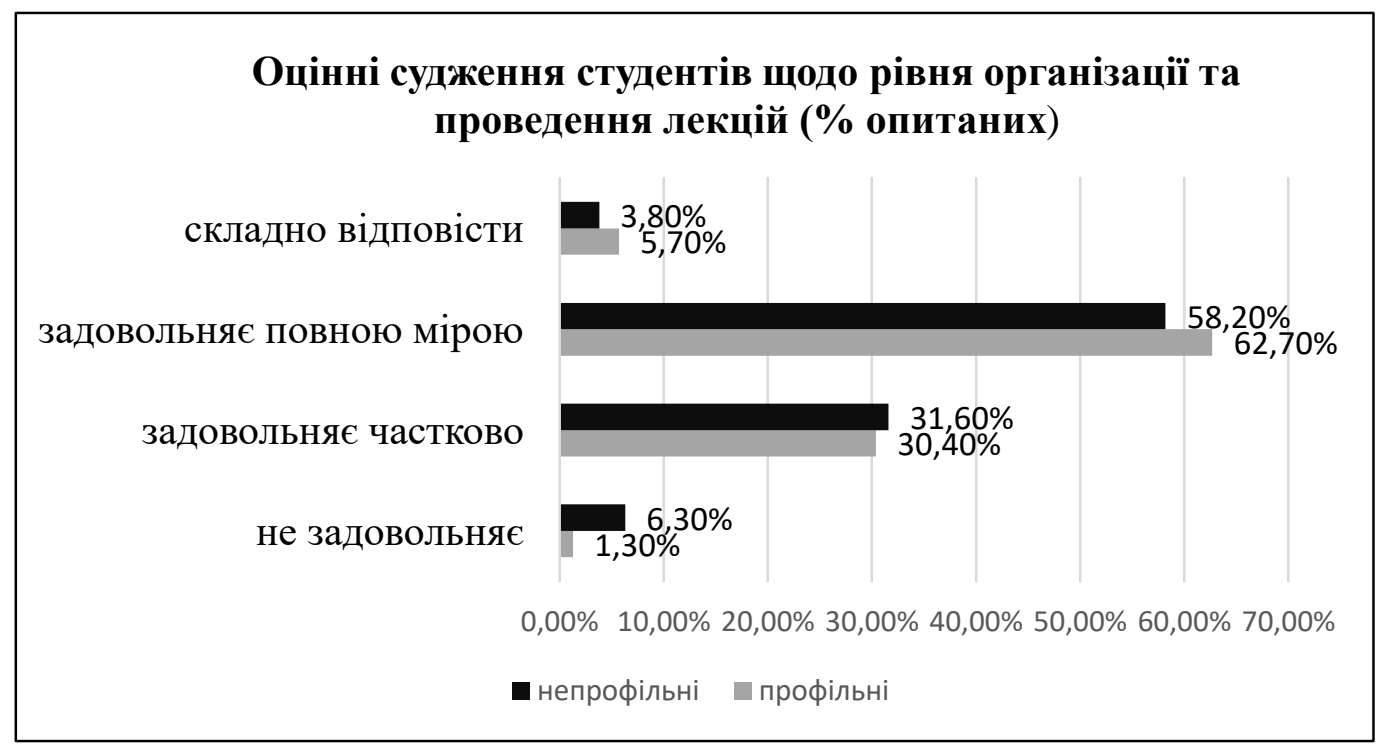

Рuc. 2. Рівень організації та проведення лекцій на думку студентів (\%, від загальної кількості опитаних)

Найнижчий рівень задоволеності студентів щодо рівня організації та проведення лекцій та практичних, семінарських занять з непрофільних дисциплін. У зв'язку з цим виникає необхідність звернути увагу викладачів непрофільних дисциплін на можливість оновлення курсів лекцій з акцентом на специфіку спеціальності, на якій здійснюється викладання. Теж саме стосується і семінарських занять (рис. 3).

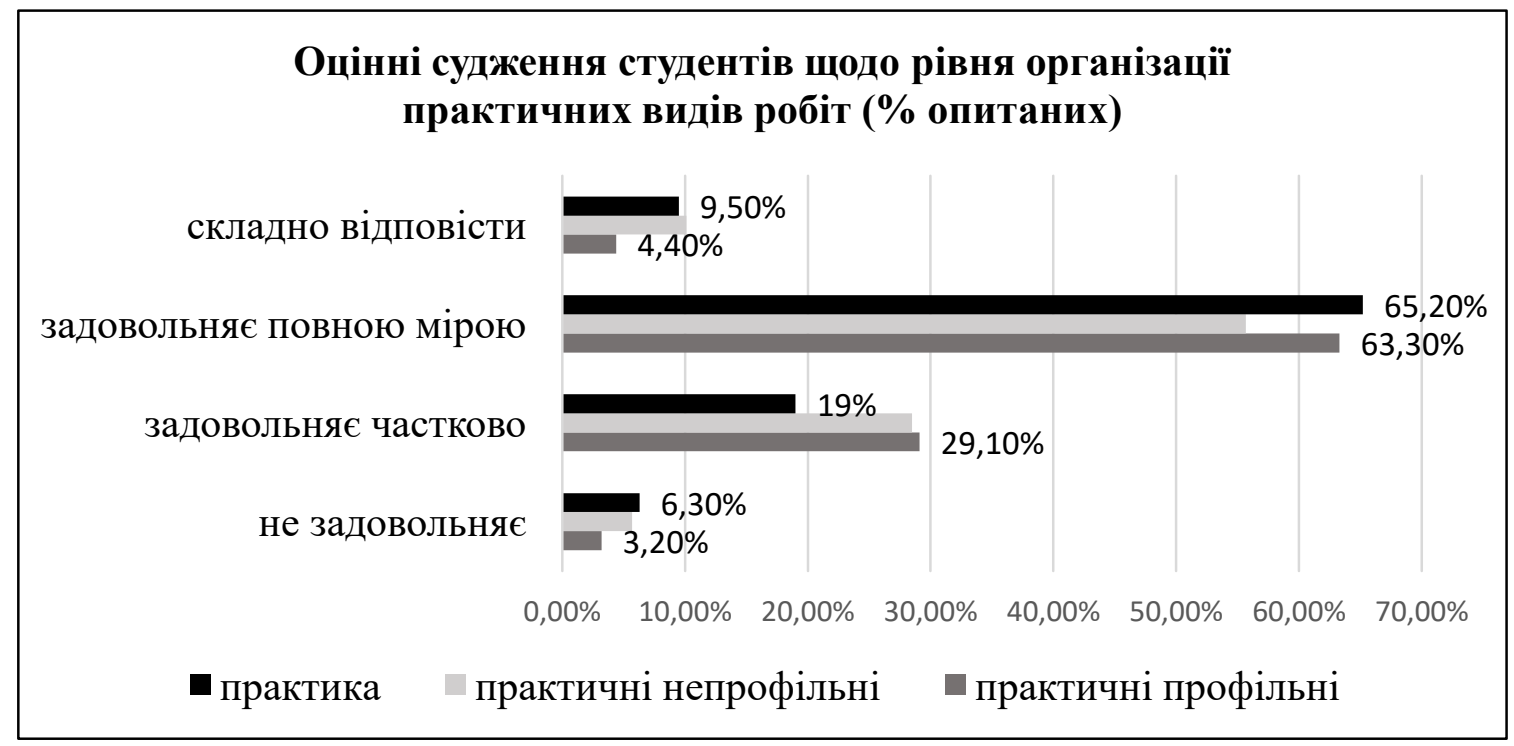

Рuc. 3. Рівень організації та проведення практичних (семінарських, лабораторних) занять 3 профільних та непрофільних предметів, практики на думку студентів (\%, від загальної кількості опитаних)

Майже половина першокурсників $(41,1 \%)$ не визначилися у своїх оцінках щодо рівня організації та проведення практики, оскільки навчальними планами підготовки не передбачено проходження практики у I семестрі першого навчального року. У той час як більшість студентів інших курсів задоволені й практикою також. 
Оцінюючи діяльність викладачів, студенти, визначили рейтинг якостей викладачів, які на їх думку є найважливішими:

1) компетентність у предметі, високий рівень викладання й організації занять

2) зацікавленість у тому, щоб студенти отримали якісні знання

3) нетрадиційність проведення занять, креативність

4) демократичне ставлення до студентів

5) об'єктивність (справедливість) в оцінюванні досягнень студентів.

Важливим чинником здобуття нових професійних знань вважається чинник відвідування занять. Із загального числа опитаних студентів не пропускають заняття всього лише 23,6\%. Цілком логічним $є$ те, що студенти першого курсу відвідують заняття значно сумлінніше, ніж студенти старших курсів. 3 тих хто пропускає заняття, переважна більшість $(43,3 \%)$ пропускає їх 3 поважних причин, майже кожен п'ятий опитаний студент факультету фізичного виховання та спорту не відвідує заняття, коли зайнятий на роботі $(21,3 \%)$. Нажаль чи не кожен десятий студент не ходить на пари через те, що йому нецікаво на заняттях $(9,6 \%)$.

Аналіз ступеню задоволеності студентами щодо здійснення вибору на користь університету, факультету, спеціальності дає уявлення про те, чи виправдалися очікування абітурієнтів щодо вступу. Студентам факультету фізичного виховання та спорту було запропоновано питання "Якби Вам знову довелося обирати факультет, спеціальність чи обрали б Ви їх цього разу?”. Обнадійливим є той факт, що більшість опитаних студентів не розчарувалися у виборі щодо факультету та спеціальності (див. рис. 4).

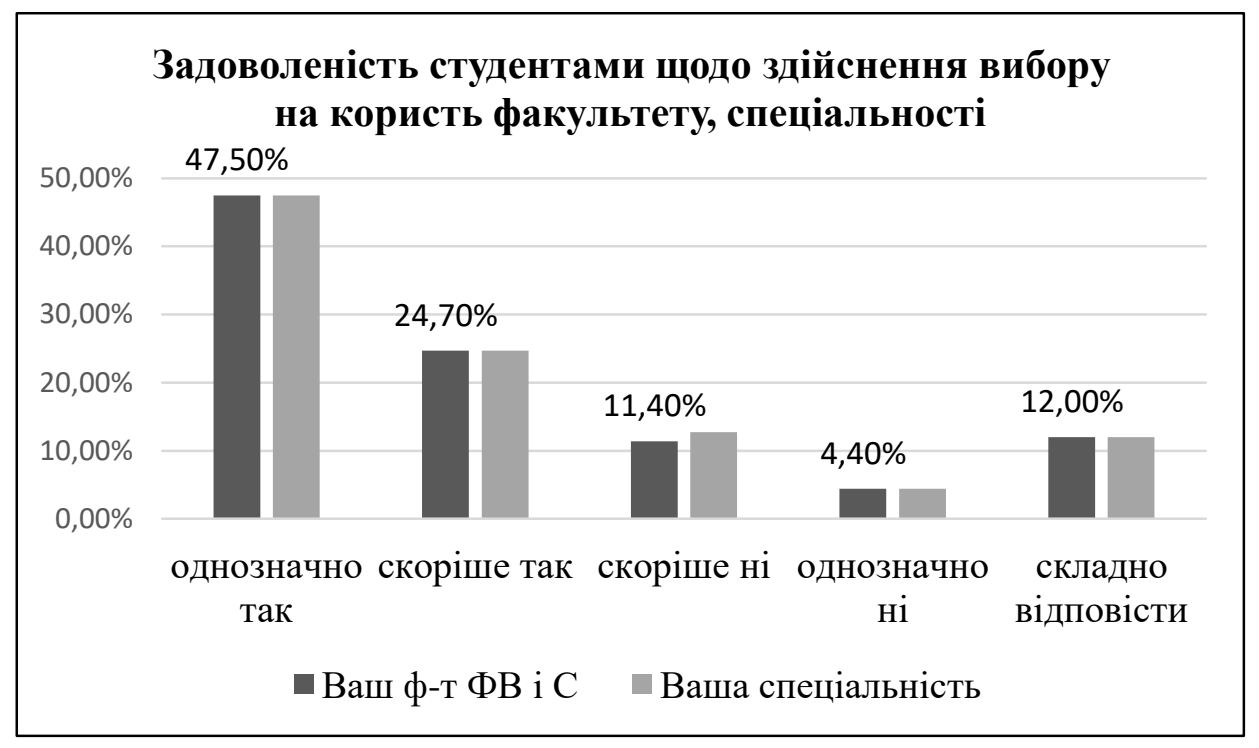

Рис. 4. Аналіз ступеню задоволеності студентами щодо здійснення вибору на користь факультету, спеціальності

Висновки. Отримані дані щодо рівня якості освітнього процесу будуть корисними у ході прийняття управлінських рішень кафедрами факультету фізичного виховання. Проведення подібних заходів дозволяє оптимізувати процес двосторонньої взаємодії між викладачами й студентами, розробляти конкретні заходи щодо цілеспрямованого вдосконалення навчальних і робочих програм з дисциплін, оптимізації навчально-виховної роботи, діяльність окремих структурних підрозділів. Результати дослідження щодо реальних потреб, цінностей, мотивації навчання студентів, сприятиме зростанню конкурентоспроможності ЧНУ ім. П. Могили на ринку освітніх послуг. 
Потрібно звернути увагу викладачів непрофільних дисциплін на якість викладання предметів, оновити як курси лекцій, так й практичні заняття, враховуючи специфіку спеціальності, на якій здійснюється викладання.

Подальші дослідження будуть спрямовані на пошук шляхів вдосконалення викладання як профільних, так й непрофільних предметів.

1. Бондаренко IГ, Бойченко ОВ, Тюветський ДО, Бондаренко ОВ. Проблеми підготовки майбутнього вчителя з фізичного виховання за результатами соціологічного дослідження. Вісник Чернігівського національного педагогічного університету імені Т.Г. Шевченка : [зб. наук. праць. Серія: Педагогічні науки. Фізичне виховання та спорт]. Чернігів. 2017; Вип. 147. Т. 1: 283-284.

2. Про вищу освіту : Закон України № 1556-VII, від 1.07.2014 чинний, поточна редакція. URL: https://zakon.rada.gov.ua/laws/show/1556-18 (дата звернення: 24.02.2019).

3. Карпюк Р. Стратегія підвищення якості вищої фізкультурної освіти. Фізичне виховання, спорт $\mathrm{i}$ культура здоров’я у сучасному суспільстві : збірник наукових праць. 2015; № 3 (31): 21-24

4. Мозальов ВЄ. Моніторинг якості освіти: вітчизняний та зарубіжний досвід. Вісник Національного університету оборони України, 2014; № 5 (42): 99-104.

5. Офіційний сайт EOSE (Европейська асоціація з питань спорту, занятості та освіти) [Електронний pecypc]. URL: http://eose.org/2015/10/exclusive-interview-with-antonio-silva-mendes/(дата звернення: 24.02.2019).

6. Офіційний сайт Міністерства освіти і науки України. URL: https://mon.gov.ua/ua/tag/yakist-osviti (дата звернення: 24.02.2019).

7. Стандарт вищої освіти України: перший (бакалаврський) рівень, галузь знань 22 “Охорона здоров'я”, спеціальність 227 "Фізична терапія, ерготерапія" : наказ Міністерства освіти і науки України від 19.12.2018 p. № 1419. URL: https://mon.gov.ua/storage/app/media/vishcha-osvita/zatverdzeni\%20standarty/ 12/19/227-fizichna-terapiya-ergoterapiya-bakalavr.pdf.

8. Шлейхер А. Найкращий клас у світі: як створити освітню систему 21-го століття / Переклала 3 англ. Ганна Лелів. Львів. Літопис. 2018. 296 с.

\section{References}

1. Bondarenko IG, Boychenko OV, Tyuvetsky DO. and Bondarenko O.V. (2017), "Problems of preparation of the future teacher of physical education according to the results of sociological research", Visnyk Chernihivs'koho natsional'noho pedahohichnoho universytetu imeni T.H. Shevchenka. Chernihiv. Vol. 147. T. 1: 283-284.

2. Verkhovna Rada (2014), Law on Higher Education No. 1556-VII.

3. Karpyuk R. (2015), "Strategy for improving the quality of higher physical education", Fizychne vykhovannya, sport i kul'tura zdorov'ya u suchasnomu suspil'stvi. Vol. 3 (31): 21-24.

4. Mozalov VE. (2014), Monitoring the quality of education: domestic and foreign experience. Visnyk Natsional'noho universytetu oborony Ukrayiny. Vol. 5 (42): 99-104.

5. European Observatoire for Sports and Employment (2015). URL: http://eose.org/2015/10/exclusiveinterview-with-antonio-silva-mendes.

6. Ministry of Education and Science of Ukraine (2019). URL: https://mon.gov.ua/ua/tag/yakist-osviti.

7. Ministry of Education and Science of Ukraine (2018), Standard of higher education of Ukraine: the first (bachelor) level, area of knowledge 22 "Health", specialty 227 "Physical therapy, Ergotherapy". URL: https: //mon.gov.ua/storage/app /media /vishcha-osvita/zatverdzeni\% 20standarty/12/19/227-fizichna-terapiyaergoterapiya-bakalavr.pdf.

8. Schleicher A. (2018), "The best class in the world: how to create an educational system of the 21 st century" translated by Anna Lelov. Lviv. Chronicle. 296 p.

\section{Цитування на цю статтю:}

Бондаренко ІГ, Дзюбан ОВ, Кураса ГО, Бондаренко БО. Про якість освітнього процесу на факультеті фізичного виховання і спорту (на прикладі Чорноморського національного університету імені Петра Могили). Вісник Прикарпатського університету. Серія: Фізична культура. 2019 Берез 26; 33: 26-34.

\begin{tabular}{|c|c|}
\hline Відомості про автора: & Information about the author: \\
\hline $\begin{array}{l}\text { Бондаренко Ірина Григорівна - кандидат наук } 3 \\
\text { фізичного виховання і спорту, доцент, Чорномо́р- } \\
\text { ський націона́льний університе́т імені Петра́ Мо- } \\
\text { ги́ли (Миколаїв, Україна) }\end{array}$ & $\begin{array}{l}\text { Bondarenko Iryna Hryhorivna }- \text { Candidate of } \\
\text { Science (Physical Education and Sport), Associate } \\
\text { Professor (Ph. D.), Petro Mohyla Black Sea National } \\
\text { University (Mykolaiv, Ukraina) }\end{array}$ \\
\hline
\end{tabular}




\begin{tabular}{|c|c|}
\hline $\begin{array}{l}\text { Дзюбан Оксана Володимирівна - старший викла- } \\
\text { дач, Чорномо́рський націона́льний університе́т і́ме- } \\
\text { ні Петра́ Моги́ли (Миколаїв,Україна) }\end{array}$ & $\begin{array}{l}\text { Dziuban Oksana Volodymyrivna - lecturer, Petro } \\
\text { Mohyla Black Sea National University (Mykolaiv, } \\
\text { Ukraina) }\end{array}$ \\
\hline \multicolumn{2}{|l|}{ https://orcid.org/0000-0002-7417-5650 } \\
\hline $\begin{array}{l}\text { Кураса Геннадій Олександрович - старший } \\
\text { викладач, Чорномо́рський націона́льний універ- } \\
\text { сите́т і́мені Петра́ Моги́ли (Миколаїв, Україна) }\end{array}$ & $\begin{array}{l}\text { Kurasa Hennadii Oleksandrovych }- \text { lecturer, Petro } \\
\text { Mohyla Black Sea National University (Mykolaiv, } \\
\text { Ukraina) }\end{array}$ \\
\hline \multicolumn{2}{|l|}{ https://orcid.org/0000-0001-5834-4509 } \\
\hline $\begin{array}{l}\text { Бондаренко Олег Володимирович - викладач, } \\
\text { Чорномо́рський націона́льний університе́т і́мені } \\
\text { Петра́ Моги́ли (Миколаїв,Україна) }\end{array}$ & $\begin{array}{l}\text { Bondarenko Oleh Volodymyrovych - lecturer, Petro } \\
\text { Mohyla Black Sea National University (Mykolaiv, } \\
\text { Ukraina) }\end{array}$ \\
\hline & \\
\hline
\end{tabular}

УДК 37.042.1:615.825.1

doi: 10.15330/fcult.33.34-39

Лідія Доцюк, Олена Гауряк

\title{
ВПЛИВ АДАПТИВНОЇ КОРЕКЦЙНО-РОЗВИВАЮЧОЇ ПРОГРАМИ НА ФУНКЦІОНАЛЬНИЙ СТАН ПІДЛІТКІВ ІЗ ЗАТРИМКОЮ ПСИХІЧНОГО РОЗВИТКУ
}

\begin{abstract}
Розробка методів корекції рухових порушень у школярів із затримкою психічного розвитку може бути виділена як один із пріоритетних напрямків адаптивної фізичної культури як форми впливу на рухову сферу дітей, підвищення резистентності та самоконтролю. Метою дослідження було вивчення впливу методики адаптивної корекційно-розвиваючої гімнастики на функціональний стан підлітків із затримкою психічного розвитку. Адаптивно-корекційна розвиваюча гімнастика включала набір комплексу процедур, що включав застосування тілесно-орієнтованих вправ і самомасажу, використання ігор та вправ для розвитку психомоторики, психокорекиійні ігри, дихальні вправи. Показано, щзо заняття $з$ адаптивної корекційно-розвиваючої гімнастики призводять до істотного покращення показників морфо-функиіонального стану та зниження рівня стресу.
\end{abstract}

Ключові слова: затримка психічного розвитку, адаптивна фізична культура, функціональний стан організму.

Despite the prevalence of physical therapy methods in the medical rehabilitation of patients with somatic diseases, in some areas of modern medicine insufficient attention is paid to the development of adequate methods for the application of therapeutic physical culture. the development of methods for correction of motor disorders in schoolchildren with a delay in mental development can be highlighted as one of the priority areas of adaptive physical culture as a form of influence on the motor sphere of children, correction of motor insufficiency, rehabilitation of motor disorders, increase of resistance and self-control [11]. The solution to the problem of the integration and socialization of children with mental retardation in the life of modern society is mainly in the field of regenerative medicine, therapeutic and adaptive physical culture and is associated with the development of new therapeutic and practical and restorative technologies in order to restore the functional reserves of the body, compensate for lost functions and increase the level of health and quality of life of people with disabilities.

The purpose of the study was to study the influence of the method of adaptive correction-developing gymnastics on the functional state of adolescents with a delay in mental development. A set of research methods was used to solve the set tasks, including theoretical analysis and generalization of data of scientific and methodical literature; observation; methods of assessing the morphofunctional state, motor readiness, psychoemotional state; pedagogical experiment: mathematical and statistical processing of experimental data.

It is shown that classes on adaptive correction-developing gymnastics lead to a significant improvement in the indicators of morphofunctional status. Under the influence of an adaptive correction-development program, the number of students with a delay in the mental development of major groups, experiencing varying degrees of stress, greatly decreases.

Key words: mental retardation, adaptive physical culture, functional state of the organism. 